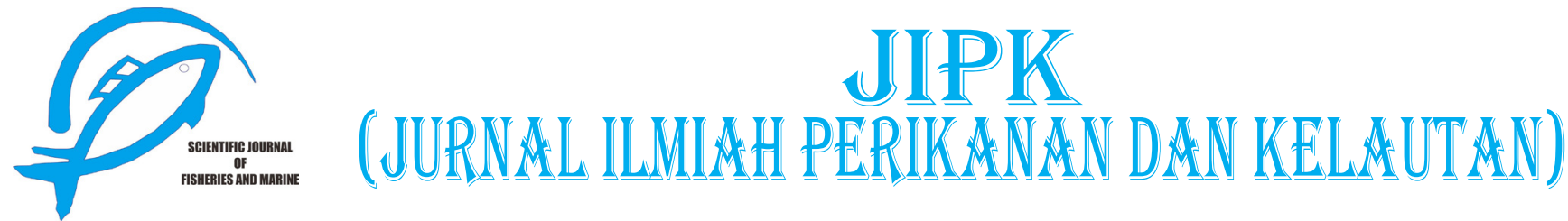

Research Article

\title{
Innovation in Financing Coastal Village Development through Community-Owned Microfinance Institution: A Case Study of Village Credit Institution (LPD) Kedonganan Bali
}

\section{Inovasi Pembiayaan Pembangunan Desa Pesisir Melalui Lembaga Keuangan Mikro Berbasis Masyarakat: Studi Kasus di Lembaga Pekreditan Desa (LPD) Kedonganan Bali}

\section{Suadi*1, Ratih Ineke Wati ${ }^{2}$, Nakagawa Mitsuhiro ${ }^{3}$}

${ }^{1}$ Laboratory of Fishery Socioeconomics, Department of Fisheries, Gadjah Mada University, Indonesia.

${ }^{2}$ Laboratory of Agricultural Extension and Communication, Faculty of Agriculture Gadjah Mada University, Indonesia.

${ }^{3}$ Laboratory ofInternationalAgriculturalDevelopment, DepartmentofRegionalandEnvironmentalScience, IbarakiUniversity, Japan

\section{ARTICLE INFO}

Received: September 20, 2019 Accepted: October 19, 2019

*) Corresponding author: E-mail: suadi@ugm.ac.id.

\section{Keywords:}

microfinance, collective actions, social capital, community development, Bali

\section{Kata Kunci:}

keuangan mikro, aksi kolektif, modal sosial, pemberdayaan masyarakat, Bali

\section{Abstract}

Microfinance institutions (MFIs) is a worldwide movement. This study aims to describe the key conditions in the rapid development of community-owned MFIs, namely LPD (Lembaga Perkreditan Desa/ Village Credit Institution), through case study in LPD Kedonganan Village, Badung Regency of Bali. This village was selected for few reasons i.e. the shifting of people livelihood from fishery-based to tourism-related livelihood, the well-manage of coastal commons for fishery, tourism spot, and religious-related activities. Data collection was conducted through several visits during 2007 to 2018. This research adopted qualitative approach through observation and depth-interview with local leaders, MFI managers and users to discover their perspective about the MFI. Secondary data was also collected from various reports of LPD Kedonganan. The study showed that LPD was established, owned, and managed by the community through a custom village. LPD distributed credits to various components of the society and business including tourism and fisheries-related business, in and out of village territory, and to male and female customers, with various types, scales, and sectors. The healthy financial performance of the institution was clearly depicted by its rapidly growing profit and equity, and its low percentage of a non-performing loan for more than three decades. The better growing LPD has attracted various socio-economic investments in the grass root, for example a collective-owned and managed seafood restaurant. Overall, the study identified that the community had made such successful and sustainable collective-owned resource arrangement. The arrangement had been evolved and built by sharing rules linked to community values, customs and faith. As a result, the emerging institutions had contributed remarkable roles to rural socio-cultural and economic development and showed the opportunity to enhance some cooperative behaviors for sustainable governance of resources and rural livelihood.

Abstrak

Lembaga keuangan mikro (LKM) telah menjadi gerakan yang mendunia. Penelitian ini bertujuan untuk menggambarkan faktor-faktor keberhasilan pengelolaan LKM berbasis masyarakat, yaitu LPD (Lembaga Perkreditan Desa), melalui studi kasus di LPD Desa Kedonganan, Kabupaten Badung Bali. Desa ini dipilih karena beberapa alasan antara lain terjadi pergeseran cepat sumber penghidupan masyarakat dari berbasis perikanan (sektor primer) ke pariwisata (sektor tersier), desa mampu mengelola sumberdaya milik bersama di pesisir secara baik untuk kegiatan perikanan, tempat wisata, dan kegiatan terkait keagamaan/budaya. Pengumpulan data dilakukan melalui beberapa kunjungan selama tahun 2007 hingga 2018. Penelitian ini mengadopsi pendekatan kualitatif melalui observasi dan wawancara mendalam dengan para pemimpin lokal, manajemen LPD, dan pengguna untuk memahami perspektif mereka tentang LKM. Data sekunder juga dikumpulkan dari berbagai laporan LPD Kedonganan. Penelitian ini menunjukkan bahwa LPD didirikan, dimiliki, dan dikelola oleh masyarakat melalui desa adat. LPD mendistribusikan kredit ke berbagai komponen masyarakat dan bisnis termasuk pariwisata dan bisnis terkait perikanan, melingkupi pengguna dalam dan luar wilayah desa, dan kelompok laki-laki dan wanita, dengan berbagai jenis, skala, dan sektor ekonomi. Kinerja keuangan lembaga yang sehat secara jelas ditunjukkan dengan laba dan ekuitasnya yang berkembang pesat, dan rendahnya pinjaman bermasalah selama lebih dari tiga dekade. LPD yang tumbuh lebih baik telah menarik berbagai investasi sosial-ekonomi di masyarakat, misalnya restoran makanan laut yang dimiliki dan dikelola secara kolektif. Secara keseluruhan, penelitian mengidentifikasi bahwa masyarakat mampu mengelola sumber daya yang dimiliki secara kolektif secara menguntungkan dan berkelanjutan. Model pengelolaan tersebut telah dikembangkan dan dibangun dengan berbagi aturan yang terkait dengan nilai-nilai masyarakat, adat istiadat, dan kepercayaan. Model kelembagaan ini telah berperan penting bagi pembangunan sosial-budaya dan ekonomi pedesaan dan menunjukkan peluang untuk meningkatkan perilaku kerja sama untuk tata kelola sumber daya dan mata pencaharian pedesaan yang berkelanjutan.

Cite this as: Suadi, Ratih, I. W., \& Nakagawa, M. (2019). Innovation in Financing Coastal Village Development through Community-Owned Microfinance Institution: A Case Study of Village Credit Institution (LPD) Kedonganan Bali. Jurnal Ilmiah Perikanan dan Kelautan, 11(2):1-10. http://doi.org/10.20473/jipk.v11i2.15733 


\section{Introduction}

Microfinance institutions (MFIs) have become a worldwide movement (Von Pischke, 2008) and contribute to various types of small-scale economy including positive change in the income levels (Swamy, 2019). Besides formal institutions such as banks and cooperatives, there are various numbers and types of semi-formal and informal microfinance institutions. This study discussed a semi-formal type of MFIs namely LPD or Lembaga Perkreditan Desa (Village Credit Institutions), which emerges as a center of finance for many rural socio-economic activities in Bali, Indonesia. It is owned and managed by the custom village (natural village), a traditional village institution in a province. Since formally established in 1984, it had rapidly expanded in its number, customers and total assets. The number of Village Credit Institutions (LPD) rose from eight units in the early 1985 (initiation project) to more than 1,400 units recently, or it might assume that almost all villages have a unit of LPD. The LPD's total assets also increased remarkably, from IDR 1.4 trillion in 2004 to IDR 3.4 trillion in 2008, and it expanded to IDR 6 trillion in 2011 and reached IDR 14.69 trillion in December 2015 (http://www.biroekbang.baliprov. go.id). In the case of LPD Kedonganan, based on data of our previous work the assets increased by $21 \%$ and profits rose $13 \%$ every year until 2014. In the same period, LPD Kedonganan savings, deposits, and credits rose to $23 \%, 20 \%$, and $19.5 \%$, respectively (Wati et al., 2016). Based on record in September 2016, the credit distributed to 1.580 people in various sectors of the economy and mainly productive economy such as trading, tourism/transportation, and investment with low non-performing loans (doubtful 5.6\% and loss $0.3 \%$ ).

Kedonganan Village, until early of the 1990 s, is a well-known fishing village and became one of the Bali sardine fisheries centers. However, the village continues to grow, becoming one important tourism spot in Bali, especially for seafood culinary tourism. Our previous research has shown that villagers have successfully managed about 1 (one) kilometer length of village beach for the well-organized business areas for fisheries and culinary tourism spot (Suadi and Nakagawa, 2009). In 2012, the government built Kedonganan fishing port as part of the minapolitan project and was inaugurated in 2014. According to Decree of the Minister of Maritime Affairs and Fisheries No. 36 the Year 2016, the port is categorized as a fish landing place (D-type). The better and availability of this fishing port has an impact on increasing fish production in Badung Regency. Rini et al. (2017) indicated that the Kedonganan fishing port production increased from 1,878 tons in 2012 to become 4.070 tons in 2016, with values increased more than 4-folds. However, the study suggested improving the quality of fish landed and the improvement of the port class, from D-type to C-type. To support business development in the village, the LPD has strategic roles in supporting and providing funding for productive business activities.

The LPD Kedonganan may become one of the examples of how a semi-formal microfinance institution had played important roles for the rural economic development, social capital formations and preservation of customs and community belief (community building). Differ from the common MFIs, which had strong economic and/or financial orientations, LPDs showed their strong position to balance with some socio-cultural roles. Furthermore, MFIs also played a remarkable role to grow entrepreneurship in the grass-root by promoting collective owned and managed businesses such as seafood restaurants in coastal areas in a center of tourism spots in Bali (Suadi and Nakagawa, 2009). How many and what kind of achievements have been realized? What kind of condition does contribute to the rapid growth of the institutions? Those questions are research questions that were discussed in this study.

\section{Materials and Methods}

This study is updating data, finding and part of previous work and unpublished thesis (Suadi, 2010). A case study had been studied in LPD Kedonganan Village, Badung Regency of Bali. An in-depth interview was conducted with local leaders, LPD managers and users including the fishermen and business persons in tourism- related businesses to discover their perspective about the MFI. Observation and secondary data were also collected from various reports of LPD Kedonganan during site visits from 2007 to 2018. A qualitative approach was used to study the research issues, as suggested by Meinzen-Dick et al. (2004). By adopting the social capital framework of Woolcock (1998), this study will discuss the factors of the successful achievement of LPD Kedonganan to support the rural economic and social life. These factors were pooled into two main groups: (1) associated social capital factors, which link the social ties: (i) within the local communities and (ii) civil society with macro-level institutions; and (2) autonomous social capital which characterizes link: (i) between local communities with external communities and (ii) within the corporate sector institution. 


\section{Results and Discussions}

\subsection{General Profiles of LPD in Bali}

LPD in Bali was established after the initiation of the seminar on rural credit by the Ministry of Home Affairs on 20-21 February 1984 in Semarang, Central Java. The government of Bali, which was led by Professor Ida Bagus Mantra, initiated the establishment of LPD (Governor Decree No. 972/1984 on 1 November 1984). The governor's policy was intended to associate the institution to the custom villages, not to the administrative ones. For example, in similar projects in other regions showed the local government more concerned to preserve the traditional rural life that has a strong connection with Hinduism. Before LPD was established, the custom village relied their finances on land rent, coconut crop, and other income sources, which seemed not adequate to support Kahyangan Tiga, a temple as a center of rural socio-culture and religious life. Meanwhile, the existence of custom villages was also challenged by the rapid modernization, growth of tourism industry, and uniformity of village institutions by the central government. The LPD, therefore, was developed not only to support the financial resources for the village, but also to promote robust autonomy and sustainability of this traditional village institution. As an institution, which is closely linked to Hinduism, the custom village plays important role in balancing three main components of Balinese life, such as Tri Hita Karana or the three causes of harmony and happiness.

The first component is the good relationship between humans and the Creator (parhyangan); second, the harmony of the relationship between human itself (pawongan); and third, harmony between humans with their environment (palemahan). It is believed that if parhyangan, represented by the existing of "Kahyangan Tiga" (temples), is well arranged and in the well state, it could give strong vibration to the arrangement of rural life related to palemahan and pawongan. This philosophy also is believed to influence the performance of economic activities such as MFIs or LPD. Therefore, many of LPDs have spent billion-rupiah investment on the religious-related facilities to enhance good performance of village socio-economic and religious life.

As a pilot project, the Bali government established LPD in eight custom villages. This project was initiated through initial capital as much as IDR 2 million per LPD in the middle of the 1980's, and it was increased up to IDR 10 million in 2000. This program had been achieved many positive responses by the village leaders and communities; therefore, LPD was finally initiated in each village recently. In terms of numbers, LPD had been remarkably increased to 1,418 units with total assets about IDR 3.4 trillion in 2008 (LPD 2008), and the total number of LPDs had increased to 1,418 units (total assets of IDR 6.4 trillion at the end of 2011). Ninety-four percent of them were categorized as wellperformance institutions based on CAEL rating (Patria, 2013). The revitalization of the custom village and the emerging of regional autonomy had a strong influence on the expansion of LPD units (in 1999 or before the autonomy era, the total number of LPD was only 913 units).

Most of LPD grew with its uniqueness of the village depending on the diversity of the natural resources and community livelihood. Therefore, LPD economic activities might base on agriculture, fisheries, animal husbandry, tourism, and business, etc. Recently, there found a strong effort to drive LPD product orientation toward the cultural-based of Balinese. As later shown for Kedonganan case, it formulated various products related to culture, for instance: free cremation ceremony product and savings for ceremony preparation that could attract more customers to use their services. Those findings indicated a different figures of this study compared to another study in Africa. In Africa, Patel et al. (2012) explained that the indigenous system was not as strong or effective as before since youth in rural areas migrated to cities. On the other hand, this study showed the rapid growth of LPD numbers and users and many programs for youth.

LPD could be seen as a remarkable institution since it played a unique and important role in socioeconomic development in Bali. The uniqueness of LPD could be found from its characteristics: (1) its regulatory framework was based on a regulation of Balinese government; (2) it was self-managed and self-governed which was integrated to the custom village rules; (3) it received small initial capital, but then became a selffinanced institution, and (4) its control mechanism was based on the cultural and religious values. Nevertheless, in terms of product and service, LPD had a similar characteristic with the bank, particularly Rural Credit Bank called Bank Perkreditan Rakyat or BPR. In terms of membership, it had a few similarities with the cooperative. The service priority was served to members of the custom village while the outsiders might access the LPD's credit services by getting a guarantee from the custom village member (called bebotoh system). However, the regulatory framework of LPD was only based on the provincial government regulation and not under the supervisor of Bank of Indonesia as a commendation by the law. The characteristics of LPD were compared with two other formal financial institutions as described in the following Table 1. 
Table 1. Characteristics of LPD in comparison with other financial institutions

\begin{tabular}{|c|c|c|c|}
\hline Descriptions & Banks & Cooperatives & LPD \\
\hline Corporation & $\begin{array}{l}\text { Limited liability, } \\
\text { cooperation, and } \\
\text { regional-owned } \\
\text { company }\end{array}$ & Cooperatives & $\begin{array}{l}\text { Not bank, not cooperatives, village- } \\
\text { owned MFIs }\end{array}$ \\
\hline $\begin{array}{l}\text { Covering } \\
\text { region }\end{array}$ & $\begin{array}{l}\text { Village, sub-district \& } \\
\text { district }\end{array}$ & $\begin{array}{l}\text { Village or bounded with } \\
\text { the types of cooperatives }\end{array}$ & Limited to the customary village \\
\hline $\begin{array}{l}\text { Capital } \\
\text { resources }\end{array}$ & Private and/or state & Members & $\begin{array}{l}\text { Reserves, community, and } \\
\text { supported fund from government }\end{array}$ \\
\hline Ownership & Private or state & Member & Customary village/community \\
\hline Product & $\begin{array}{l}\text { Saving, credit, and } \\
\text { deposit, clearing, and } \\
\text { commercial study }\end{array}$ & Saving and credit & Saving, credit, and deposit \\
\hline Customers & Public & Priority for the members & $\begin{array}{l}\text { Customary village members; Non- } \\
\text { member need member guarantor }\end{array}$ \\
\hline $\begin{array}{l}\text { Social } \\
\text { responsibility }\end{array}$ & $\begin{array}{l}\text { Tax payment and } \\
\text { corporate social } \\
\text { responsibility }\end{array}$ & $\begin{array}{l}\text { A social fund such as } \\
\text { sympathetic care for a } \\
\text { member }\end{array}$ & $\begin{array}{l}\text { Direct financial support to the } \\
\text { customary village }\end{array}$ \\
\hline Supervisor & $\begin{array}{l}\text { Bank of Indonesia or } \\
\text { other bank permitted } \\
\text { by regulation }\end{array}$ & $\begin{array}{l}\text { Ministry of Cooperation } \\
\text { or other name related to } \\
\text { cooperatives }\end{array}$ & $\begin{array}{l}\text { Bali Province development bank } \\
\text { (BPD) }\end{array}$ \\
\hline Regulation & $\begin{array}{l}\text { The } 1992 \text { Banking } \\
\text { Act, amended in } 1998\end{array}$ & The 1992 Cooperation Act & $\begin{array}{l}\text { The } 2002 \text { Bali Province Regulation, } \\
\text { revised } 2017 \text { and the } 2013 \\
\text { Microfinance Act }\end{array}$ \\
\hline
\end{tabular}

Sources: Local regulation 3/2007, UU No. 10/1998, UU 25/1992, UU 1/2013, and deep interviews

\subsection{Economic and Socio-Cultural Roles of LPD Kedonganan}

LPD Kedonganan was established on 9 September 1990, six years after the initiation of rural finance policy by the government of Bali in 1984. In the early beginning, the initial capital was IDR 2 million given by the provincial government and IDR 2.6 million given by Badung Regency. The custom village as an LPD owner could not give any financial support because of its unable condition, yet it was only able to give moral support for its establishment. Therefore, LPD set up with total initial capital as much as IDR 4.6 million. It was such a small amount budget that might boost the manager to be optimally creative to allocate the financial. To increase the LPD fund, the manager, fortunately, could get access to a bank loan with his guarantee.

One day, the problem came since the community of the village reckoned that the name of the village contained negative meaning (does not bring luck since kado in the Balinese word means failure). However, the institution could tackle the trust issue by giving a target and announcing its benefit (for renovating their temples). As time goes by, LPD was positively accepted, and it rapidly grew as well as they finally could renovate the temple. What first being renovated was Pura Dalem Kahyangan. It spent more than IDR 200 million from its profit. By 2005, all village temples (Pura Penataran, Pura Segara, and Gedong Ratu Ayu) were redecorated, and there was a new temple that was constructed, and it spent a total amount of investment more than four billion rupiahs.

The astonishing performance of LPD Kedonganan was seen from its financial achievement. Its profit and equity remarkably raised from only IDR 4 million a year to IDR 3 billion in 2000 after establishments and more than IDR 11 billion in 2017. Overall, its financial performance was in terrific condition. Therefore, the previous problem which came from the term kado that meant failure in the Balinese term currently became kado which meant gift or present in Indonesian term (Indonesia text). Until 2017, the total assets of LPD reached IDR 330.5 billion, which had been remarkably increased since its establishment in 1990, which was 
JIPK. Volume 11 No 2. November 2019 / Innovation in Financing Coastal Village Development through Community-Owned ..

only IDR 67 million, or rose 4,93-folds in less than three decades. Within the same time, the institution had released credit with a total amount of IDR 206 billion and received saving as much as IDR 141 billion. The following table explains the general performance of LPD Kedonganan between 1990 and 2017 (Table 2). the tourism industries. The changes in rural livelihood would probably effect the way people in adapting and coping with any external changing of their micro and macro socio, economic, and politic environment.

The LPD, in fact, had economic activities limited to the custom village territory, but its network had a wide

Table 2. Total asset, saving, and loan in LPD Kedonganan, 1990-2017

\begin{tabular}{|c|c|c|c|c|c|}
\hline Year & Asset (IDR) & Saving (IDR) & $\begin{array}{l}\text { Deposit Account } \\
\text { (IDR) }\end{array}$ & Loan (IDR) & Profit (IDR) \\
\hline 1990 & $67,824,000$ & $52,161,000$ & $3,000,000$ & $66,275,000$ & $4,063,000$ \\
\hline 1995 & $1,732,687,000$ & $601,052,000$ & $748,750,000$ & $1,283,798,000$ & $152,513,000$ \\
\hline 2000 & $14,721,603,000$ & $6,474,975,000$ & $4,987,950,000$ & $11,853,665,000$ & $1,540,632,000$ \\
\hline 2005 & $48,146,226,000$ & $17,984,531,000$ & $19,075,751,000$ & $43,483,141,000$ & $2,965,066,000$ \\
\hline 2010 & $136,019,081,000$ & $51,276,249,000$ & $56,041,250,000$ & $104,222,723,000$ & $4,446,082,000$ \\
\hline 2015 & $266,276,995,000$ & $114,941,361,000$ & $93,291,000,000$ & $198,742,838,000$ & $11,105,458,000$ \\
\hline 2017 & $330,515,583,000$ & $141,563,318,000$ & $118,170,230,000$ & $206,062,795,000$ & $11,597,185,000$ \\
\hline
\end{tabular}

LPD Kedonganan had distributed credit to various groups of people and some economic activities. The credit distribution was allocated for working capital, investment, and consumer credit. Based on data in August 2009, There was about $52.3 \%$ of credit allocated for working capital and $36.9 \%$ for investment credit. The share of consumption credit was the lowest $(10.8 \%$ of the total allocated credit), but in terms of the number of the customer was the highest contributed by $36.9 \%$ of the total customer. According to the sector of economic activities, the allocation of credit was dominated by services and business sector that was represented by trading and business $(56 \%$ of total credits and $60 \%$ of customers) and tourism and transportation (14\% of total credits values and $10 \%$ of customers). The primary sector, which was respectively represented by fisheries and agriculture sector contributed only $0.3 \%$ and $3 \%$ of total customers and $2.5 \%$ and $0.1 \%$ of total credit values. On average, the credit allocation for tourism and transportation was placed on the top accounted for more than IDR 60 million per person. Indeed, the recent data (September 2016) also showed the similar figure in which the credit is mostly distrusted for the productive economy such as trading $(62.8 \%)$, tourism/ transportation $(20.2 \%)$, and investment $(11.5 \%)$. Not only for men, but women are also the main customer of LPD. Women used in the smaller amount of credit than men with an average of IDR 37 million per person while men used about IDR 65 million, and therefore, LPD has become an important financial resource for small-scale economic activities and raised women's participation.

These data represented a significant shift of rural livelihood reported as the fishing village (primary sector) before the 1990's. Now, it included the trading and business activities which most of them related to range of areas covering non-custom village members (in local called non-krama desa) and whose region outside of the village and regency. The opportunities of the outsiders to use the LPD services could be realized as LPD allowed the borrowers to use its services since they have a guarantor from the member of the custom village (bebotoh in the Balinese language). Debtors from outside of the village were calculated by about $28.8 \%$ of the total. Through such a strategy, LPD could gain higher benefits because the interest rate for the non-member was higher than a member. The stable performance of the institution was clearly shown by a low level of non-performance loan since the early time of its establishment. Based on data in 2009, it was more than $96 \%$ of credit in standard and sub-standard state (health and sound) and only $1.8 \%$ of total credit calculated as a loss (no sound). The recent data also shows LPD keeps a similar figure with still low non-performing loans $(94.1$ on standard and sub-standard, doubtful 5.6\%, loss 0.3\%). Therefore, such a position showed the opportunities for such community-based enterprises to fulfill the need for financial resources for productive and consumptive activities in the rural socio-economic communities.

Furthermore, based on the savings, the total saving remarkably increased since the establishment of this institution. In 1990, the voluntary savings and deposits were about IDR 52 million and IDR 3 million, and then they increased to IDR 28.4 billion in 2000 and IDR 141 billion in 2017. LPD provided various types of savings that were related to the economic, socio-cultural, and religious life of the villagers. In religious life (parhyangan), it promoted Sipadat (savings to prepare ritual ceremony) aimed to make people had better preparation in funding their rituals and ceremonies called Panca Yadnya (Five Immolations) 
which was often expensively charged. This savings type was particularly promoted to custom village members. To increase the better human relationship (pawongan), LPD also promoted Tindak, a type of investment that was particularly promoted to the custom villagers. Meanwhile, realizing the needs of human capital improvement, it promoted Tabeplus as saving for education. It was a way to educate children to save money and to attract their family to prepare tuition fee for higher-level education. Also, to attract customers, it explained that all saving accounts with a certain minimum balance had the opportunity to win a coupon of the prize in every transaction. Therefore, to serve the customers, it also provided door - to - door services to facilitate depositors and debtors. The saving accounts also could be used as collateral to get credit accesses. However, the striking increasing number of savings has changed the composition of credit to saving. During the 1990 s to the early 2000 s, credit was just placed above saving; however, the trend indicated that savings were higher than credit. It represented that it received high participation and trust from the villagers. Nevertheless, the safe and profitable investment from liquidity required avoiding the institution from the payment of interest rate for savings.

The socio-culture aspect of LPD related to its functions that were not merely to generate economic benefits. It was clearly described by its regulation that it needed to share its profits with the owners (custom village) and allocated its profit for social funds. The local regulation stated that twenty percent of its net profit was allocated for village development and five percent for the social fund (Regional Regulation or PERDA No 3/2017). Development fund had increased significantly by 824 -folds, from IDR 813 thousand in 1990 to IDR 308.1 million in 2000 and became IDR 670 million in 2007. Similarly, the social fund had dramatically raised from IDR 203 thousand in 1990 to IDR 47.4 million in 2000 and IDR 83.7 million in 2007. LPD also creatively managed its fund to support rural religious life. For example, by taking the administrative fee as much as IDR 1,000 and IDR 2,000 per customer, the LPD could fully afford to fund the mass cremation ceremony (Ngaben) which had been conducted for two times, in 2006 and 2009. This type of ceremony could consume a big amount of money if it was personally conducted by a family; it ranged from 20 to 50 million rupiahs per died body. To improve the quality of human capital, it had a direct routine program for supporting the improvement of education in elementary school in the village, for example: academic and writing competition and scholarship as a part of its anniversary program. As a gift for the improvement of the education process, it fully supported the development of TK Dharma Putra (kindergarten) with a total investment of IDR800 million.

The rapid growth of LPD had gained various responses from the villagers. During the focus group discussions and depth interviews, the study identified the respondents' positive responses about the institution. They reported that most communities had enjoyed its social benefit, and it had become such pride for them. Therefore, the community preferred to optimize all LPD services by at least saving their money as a way to supporting their village institution. The demands for new social services were also in raising. Senior priest and former custom village head expected LPD to provide long-term housing credit for their villagers. It might be reasonable because the land was a crucial issue for this village. It was not only because of the small village area (190.7ha) with a large number of inhabitants $(11,800$ people and-a-half of them a temporary migrant), but also the strategic position of the village as one of the main tourist spots, which could be a target for investment. As a result, there would be difficult for villagers who had little money to live in their homeland without support from LPD, with long-term and low-interest rate credit.

The not all-amazing performance of LPD is praised. Few senior villagers have criticized about the easiness of getting access to credit. A senior villager (65 years old), as an example, indicates his concern in polite rhetoric that despite it has so many positive aspects, it also affects the negative effect such as motivating the villagers to become consumptive. Nowadays, we often hear that kids force their parents to buy a new motorbike because they have known the easy access to get money, without concerning their parents' ability. This illustration is in line with the statistical data of LPD that describes the increasing trend of demand credit for consumptive purposes. Also, the release of new regional regulation on LPD, through Regional Regulation (PERDA) No. 3/2017 and Governor Decree (PERGUB) No. 44/2017 have demanded the financial contribution of LPD at village level for coordination and empowerment at the higher administrative level (province). These have become challenges for the future institution to cover various social changes and national economic development.

\subsection{Discussion: Key Conditions for LPD Success}

As a collective owned institution, LPD shows its ability to attract collective action. Its ownership was delegated to the custom villages to strengthen community participation as well as responsibility and control over their owned resources. Therefore, this 
institution has been avoided from the fragmentation of information and knowledge in resource arrangement. The community participation of the institution could be classified as citizen power degrees (Arnstein, 1971). At this level, citizens obtain the majority of decisionmaking seats or full managerial power. Three main actors play important roles for many LPD achievements: (1) manager, (2) community (represented by their custom village as the owner), and (3) the government as a supporting institution. To explain the LPD performance this study adopted the social capital framework of Woolcock (1998).

\subsection{Intra-community network}

This network inculcates the communities, for example in a case of LPD: it ought to attribute the local faith, custom, and location. As depicted by the Bali Province Regulation on Custom village, the members of this village who are automatically the owners of the institution are those who believe in Balinese Hindu and live in the village territory. Also, the villagers who have left the village due to working and other activities still, belong to this village. Consequently, they need to show up in the village in certain ceremonies or paying some compensation as participation. This location bond may be sustainable since one day every member of the villagers must need a place to rest in peace, and in their belief, their village is a place where they come home. It also influences the economic activities, for instance, the formulation of credit, saving and sanction - for a trespasser of the institution rules. Besides, the clear identity of community makes the member could optimize all available services provided by the financial institution. Therefore, both community and LPD establish mutual benefits. This finding is in line with the fact that a community with a clear identity may produce more collective goods and higher fulfillment of collective needs (Anthony, 2005).

The ability of LPD providing various services has eased the fulfillment of various communities' needs. It gives credits based on individual, group, and business membership. The credit in general also covers productive investment and consumptive credit. Even though the direct fishing related business credit declining and shift to services and tourism-related business, but the establishment of the fishing port may attract new opportunities for LPD to finance the business particularly for post-harvest related activities including the port logistics. Meanwhile, saving also offers various forms to cover the religious-based, education-based, and voluntary savings, and most of them could be used as collateral for getting credit access. These findings suggested the needs of various products based on the community needs, in achieving the success of MFIs. The need in this context is not only financial services but also non-financial services such as for the sociocultural and religious purposes.

The benefit of the village location as one of the important tourism spots in Bali has also given a certain economic benefit for the village development and its rapid growth of LPD. It potentially provides various livelihood resources for the community. Despite the discourse about the negative effect of globalizing tourism industries which one could be potential to lessen the social ties, this study shows that the communities could optimally prosper the tourism economic opportunities without giving so much deterioration to local customs and beliefs. This type of social capital, therefore, could be seen as an asset that has existed in the society through its unique historical process and culture.

\subsection{State-society network}

The state-society network clarifies how a link between civil society (village communities and their institutions) and macro-level institutions may influence the condition and formation of social capital. This macrolevel type of social capital inculcation could be assessed from the regulation of LPD or village development policy in general and in every level of decision-making covering micro, middle, and macro-level (village, district, province, and central government). At the micro-level, the coexistence of the traditional village, as the community-based institution with the administrative village and as the lowest level of a government institution has given opportunities to perform in every role and duty they have. The collaboration of these village-based institutions is as a proof to give a higher benefit to the communities as seen on the rearrangement of the use of the village coastal area, from individual-based to collective ownership (Suadi and Nakagawa, 2009).

As occurred in many MFIs around the globe, LPD was initiated by external agencies, and in this case, it is in the provincial government of Bali. It has received initial capital from the government and the district itself. The project is delegated to the custom village, instead of the administrative village as the extension of government authority at the village level. The government's political wills to sustain the existence of the traditional village system shows a significant support for the healthy growth of this microfinance institution. This policy encourages local communities to get together and form a social networks (Fukuyama, 2001). Meanwhile, the previous existence of the custom village as an institution that has the responsibility to preserve and develop rural socio- 
cultural life might have strengthened local communities to empower their system, which in turn could assist the organization of community as a whole. Besides, for the development of LPD, the government also presupposes the custom village to have written awig-awig (custom village law) from the convention of awig-awig. As a result, this emerging social capital, which is embedded in the community, performs a better performance and may be difficult to be inoculated by the outside cultural intervention (Khan, 2006).

Some changes in national development policy, from centralized to decentralized policy, allowed regions to empower all available resources for development. The rapidly increasing number of LPD since in the early 2000s represented a result of the initiation of autonomy policy in 1999. Corresponding to grow and to promote better accountability of this MFIs, the local government gave authority to BPD (Bank Pembangunan Daerah), provincial government development bank, to give technical supervision and to be the external supervisor of LPD (Article 18 of Regional Regulation No 3/2007 and currently revised to Regional Regulation No $3 / 2017)$. Also, the advisory units in the provincial and district level were also established. The expenses for the supervision were taken from the allocation of the local government budget (province and/or district) and its share fund for guidance, supervision, and protection ( $5 \%$ of its net profit). Meanwhile, BPD had become the only bank for LPD to save its surplus liquidity funds with a competitive interest rate and adequate services. This network made LPD to have a strong connection with the formal financial institution, and it made this institutional unique role in the economic development of the region.

The discourse to regulate all forms of microfinance institutions by the law during 2009-2012 in the House of Representative (DPR, Dewan Perwakilan Rakyat) had become the main attention among LPD managers and local regulators. The draft of the Microfinance Act indicated the need for the institution including LPD Kedonganan to changing its legal form, which might give a significant impact on its management and multi-functionality for rural lives. In particular, the managers, local government and community tended to avoid this change. Fortunately, the Microfinance Act had accommodated their effort since it was stated as an exception and was not regulated based on this Act (Article 39 of Act No. 1/2013). Therefore, this regulation should need to recognize a specific characteristic of the institution and to accommodate the feasibility and scope of development that MFIs needs (Bowles and Gintis, 2002).

\subsection{Extra-community network}

Autonomous social capital at the micro-level depicts various networks between the local institutions and communities with an external and more extensive social connections to civil society. In the case of LPD Kedonganan, MFI has strong linkages with institutions and communities outside of custom village members. This network has made a good performance in LPD. As discussed previously, the outsiders cover 28.8 percent of total debtors but contribute to 41 percent of the total amount of credit allocation. Therefore, the bebotoh system has made a strong community connection with other societies outside of the village territory. These descriptions indicate that in achieving stable financial condition, LPD should have promoted a balance of a strong bonding that could strengthen associational life and tie within communities and weak bonding, which could be a bridge of the network with other communities out of its boundaries. This type of network indicates that the performance of the MFIs may much be influenced by the relationship between structure and network between and within the institution (Granoveter, 1985).

\subsection{Institutional capacity and credibility}

Custom village could be seen as both moral resources as well as moral forces. Folger (2012) describes moral resources as shared functions as resources and as norms. As moral resources, this village institution shows its potentialities to increase the supply of public goods when it is used or not. It could be also depicted as a moral force for Balinese rural life because the institution enhances social order within society. This village is an autonomy institution whose regulation is based on its own rules (so-called awig-awig), and the higher decision-making is based on the decision-making process in village deliberation (paruman desa). Through this village forum, LPD managers and supervisors are selected. Then it is under control of village rules, and both managers, as well as internal supervisors, need to inform the community through this medium. As a result, communities feel secure to use LPD services, for instance, in saving their wealth, because of the close connection of the institution with their daily life (self-regulating organization). The credibility of this institution, therefore, is not only determined by their formal qualities of an institution, but it is also strongly influenced by the ability to perform personal relationships and network between and within the firm (Granoveter, 1985).

The managers have also shown their managerial abilities and creativity in inventing products and mobilizing funds. To deal with the non-performing loan issues, besides the standard procedures adopting 
JIPK. Volume 11 No 2. November 2019 / Innovation in Financing Coastal Village Development through Community-Owned ..

Table 3. Embeddedness and autonomous components of social capital in Balinese LPD

\begin{tabular}{llll}
\hline \multicolumn{1}{c}{ Types } & \multicolumn{2}{c}{ Micro } & \multicolumn{1}{c}{ Level } \\
\hline Embeddedness & 1) & $\begin{array}{l}\text { Faith, customs and location ties (identity) } \\
\text { Diverse product and base on community } \\
\text { needs }\end{array}$ & 1) $\begin{array}{l}\text { Traditional and administrative village } \\
\text { coexistence }\end{array}$ \\
& 2) & $\begin{array}{l}\text { Regulation framework based on } \\
\text { provincial regulation }\end{array}$ \\
Autonomous & 1) & $\begin{array}{l}\text { Widening covering area and consumer } \\
\text { by adopting bebotoh system (member as } \\
\text { guarantor) }\end{array}$ & 1) $\begin{array}{l}\text { Leadership and creative management } \\
\text { including social dilemmas resolution }\end{array}$ \\
& 2) $\begin{array}{l}\text { Outsider good track record may benefit } \\
\text { certain services }\end{array}$ & $\begin{array}{l}\text { Supervision system by local bank and } \\
\text { community }\end{array}$ \\
\hline
\end{tabular}

precautionary approaches, the management is relished by the strong bonding communities. Therefore, intensive interactions within communities strengthen better problem solving related to the non-performing loans. In this case, LPD could optimize hamlet (banjar) and village meetings to deal with the malfeasance, particularly in relation to group lending. Another type of sanction has been promoted through families' responsibility for loan issues; thus, the loan would go long-lasting until it is paid by the debtor or his/her family and relatives. A clear sanction can produce more collective goods and a higher level of collective need accomplishment (Anthony, 2005). Overall, in the role of leader and leadership is remarkable as an achievement. Leadership seems important both in dealing with dayto-day matters and for long-term decisions (Ternström, 2006).

\section{Conclusions}

LPD, as a type of community-based enterprise, has contributed remarkable roles for the rural sociocultural and economic development. ILPD distributed its credit to various components of the society covering the village members and non-members, within and out of village territory, with various types, scale, and sector of economic activities, to male and female customers. The strong financial performance of the institution is depicted by its profit and equity and the low percentage of non-performing loans. The connection of economic activities of MFI within the community's socio-culture has given the opportunities for LPD managers to develop socio-cultural based programs. These programs nurture some forms of community trust, not only the trust from the local community but also outsiders as depicted by a large number of its depositors and debtors of both sides. The adequate supports from local government in terms of initial capital and supporting policies have created an appropriate environment for the institution to grow. These findings, therefore, discover a type of policies that encourage the local communities to work collectively and develop various networks that might raise better achievement in rural socio-economic development. The sound performance of LPD might be achieved because society has the willingness and ability to fertilize social connection in every level of social capital: within communities, between communities and other civil society, state-community network, and within the institution itself. Management contributes to an important factor in determining institutional effectiveness. In this particular case, the institution could balance the (1) financial goal to achieve profit from their business and (2) social goal to share the benefit with the owners (community). The future challenges of LPD may come from the communities, for example, the rapid social change from primary sector (fishery and agriculture) to the third sector (services-based), and it also may come from the outside of the institution related to the MFIs regulations, both at national and regional/provincial level.

\section{Acknowledgments}

Writers would like to appreciate to the Mr. I Ketut Madra and Mr. I Wayan Merte for their supports to all research activities and facilities during a field study in Bali for many years.

\section{Authors' Contributions}

All authors discussed the results and contributed to from the start to final manuscript; $\mathrm{Su}$ : responsible for the overall data collection and writing the initial until final draft of this paper. Rat: responsible for some data collection, particularly secondary data and finding discussions. Nak: besides being involved in a few field works, is also in the discussion of this paper.

\section{Conflict of Interest}

The authors declare that they have no competing interests 


\section{Funding Information}

This research was partially funded by MEXT Ministry of Education, Culture, Sports, Science and Technology Japan as scholarship awardee during 20042010 and research fund from Faculty of Agriculture Gadjah Mada University during 2015-2018.

\section{References}

Anthony, D. (2005). Cooperation in Microcredit Borrowing Groups: Identity, Sanctions, and Reciprocity in the Production of Collective Goods. Americould Sociological Review, 70(3): 496-515.

Arnstein, S. R. (1969). A Ladder of Citizen Participation. Journal of the American Planning Association, 35(4): 216-224.

Bowles, S., \& Gintis, H. (2002). Social Capital and Community Governance. The Economic Journal, 112(483): F419-F436

Folger R. (2012). Moral Resources. In: Törnblom K., Kazemi A. (eds) Handbook of Social Resource Theory. Critical Issues in Social Justice. New York: Springer. pp149-159.

Fukuyama, F. (2001). Social capital, civil society and development. Third World Quarterly, 22: 7-20.

Granoveter, M. (1985). Economic action and social structure: the problem of embeddednes. The Americould Journal of Sociology, 91(3): 481 $-510$.

Khan, S. R. (2006). Learning from South Asian 'Successes'. South Asia Economic Journal, 7(2): 157-178

LPD. (2008). Profile of Balinese LPD. Bali.

Meinzen-Dick, R., DiGregorio, M., \& McCarthy, N. (2004). Methods for Studying Collective Action in Rural Development. Agricultural System, 82: 197-214.

Patel, L., Kaseke, E., \& Midgley, J. (2012). Indigenous Welfare and Community-Based Social Development: Lessons from Africould Innovations. Journal of Community Practice, 20:12-31.

Patria, I. K. R. (2013). Lembaga Perkreditan Desa: UU LKM Jadi Payung Hukum, Lembaga Perkreditan Rakyat: MFI Act as Legal Protection.

http://www.bali-bisnis.com/index.php/ lembaga-perkreditan-desa-uu-lkm-jadipayung-hukum/ [accessed: 8 April 2013]

PERDA3/2003. Peraturan Daerah Provinsi Bali Nomor 3 Tahun 2003 tentang Perubahan Atas Peraturan Daerah Propinsi Bali Nomor 3 Tahun 2001 Tentang Desa Pakraman (Regional Regulation of Bali No. 3/2003 on Custom village)

PERDA 3/2007. Peraturan Daerah Provinsi Bali Nomor 3 Tahun 2007 tentang Perubahan Atas Peraturan Daerah Provinsi Bali Nomor 8 Tahun 2002 tentang Lembaga Perkreditan Desa (Regional Regulation of Bali No. 3/2007 on Village Credit Institution).

Rini, A. P. S., Bambang, A. Z. \& Wibowo, B. A. (2017). Strategi Pengembangan Pangkalan Pendaratan Ikan (PPI) Kedonganan Kabupaten Badung Bali. Journal of Fisheries Resources Utilization Management and Technology, 6 (4): 119-128.

Suadi \& Nakagawa, M. (2009). Sharing the Commons: Resolving the Tragedy of the Commons through Collaborative Management of Coastal Commons at Kedonganan Village, Bali. Journal of Kyosei Studies, 3(1): 263-285.

Suadi. (2010). Livelihood from the Commons: Conflict, Cooperation, and the Governance of Coastal Resources in Indonesia. Japan: Tokyo University of Agriculture and Technology. (unpublished thesis).

Swamy, V. (2019). Financial Inclusion and The Resilience of Poor Households. The Journal of Developing Areas, 53(4): 179-192.

Ternström, I., 2006. Leadership in Common-Pool Resources Management, Working paper of the International Association for the Study of Common Property (IASCP), http://hdl.handle. net/10535/930, re-accessed 19 October 2019.

Wati, I., Suadi, \& Nakagawa, M. (2016). Challenges for sustainable development of community based micofinance: A case study from Lembaga Perkreditan Desa (LPD) Kedonganan customary villege, Bali. Kyosei Studies, 10(1): 296-332

UU 32/2004. Undang-Undang Republik Indonesia Nomor 32 Tahun 2004 tentang Pemerintahan Daerah (Act No. 32/2004 on Regional Government)

UU 10/1998. Undang-Undang Republik Indonesia Nomor 10 Tahun 1998 tentang Perbankan (Act No. 10/1998 on Bank).

UU 25/1992. Undang-Undang Republik Indonesia Nomor 25 Tahun 1992 tentang Perkoperasi (Act No. 25/1992 on Cooperative)

von Pischke, J. D. (2008). New Partnerships for Sustainability and Outreach. In I. MatthäusMaier and J. D. von Pischke (eds),. New Partnerships for Innovation in Microfinance. Berlin: Springer-Verlag. p.1-13.

Woolcock, M. (1998). Social capital and economic development: toward a theoretical synthesis and policy framework. Theory and Society, 27(2):151-208. 